УДК 551.34:550.46

\title{
СОДЕРЖАНИЕ И СОСТАВ АТМОСФЕРНЫХ И ПАРНИКОВЫХ ГАЗОВ В ПОДЗЕМНЫХ ЛЬДАХ РАЗНОГО ГЕНЕЗИСА
}

\author{
Бутаков Владислав Игоревич 1 , \\ vladbutakov@yahoo.com \\ Слагода Елена Адольфовна2,1, \\ eslagoda@ikz.ru
}

\author{
Тихонравова Яна Витальевна ${ }^{3}$ \\ tikh-jana@yandex.ru \\ 1 Тюменский индустриальный университет, \\ Россия, 625000, г. Тюмень, ул. Володарского, 38. \\ 2 Институт криоссреры Земли ТюмНЦ СО РАН, \\ Россия, 625000, г. Тюмень, ул. Малыгина, 86 \\ 3 Институт мерзлотоведения им. П.И. Мельникова СО РАН, \\ Россия, 677010, г. Якутск, ул. Мерзлотная, 36
}

\begin{abstract}
Актуальность. Парниковый эфффект связывают с поступлением метана и углекислого газа из оттаивающих газонасыщенных льдистых пород, а их содержание в подземных льдах недостаточно изучено. Для оценки содержания газов в отложениях и льдах, объемов поступления газов в атмосфреру используют разные и несопоставимые методы отбора проб газа. При обобщении данных об углеродной эмиссии в Арктической зоне необходимо учитывать методы определения содержания и состава газов и химический состав, наличие органических и минеральных включений в генетических типах подземных льдов.

Цель: определить содержание и состав газов в распространенных генетических типах подземных льдов и мерзлых отложений; определить сопоставимость результатов разных методов отбора газа для оценки масштабов эмиссии парниковых газов в атмоссреру на фоне протаивания мерзлоты.

объекты: подземные льды сегрегационного, термокарстово-полостного и повторно-жильного генезиса, льдистье мерзлые отложения севера Западной Сибири на о. Бельй, Западном Ямале, севере Гыдана и Пур-Тазовском междуречье, собранные экспедициями ИКЗ ТюмНЦ СО РАН в 2014-2019 г2.
\end{abstract}

Методы исследования и интерпретации химического состава. Использованы два метода извлечения газа из монолитов мерзлых пород и льда: метод термовакуумной дегазации и метод «headspace». Метод термовакуумной дегазации в лабораторных условиях с определением объёма газа в образце льда был использован как рефрерентный. Состав атмосфрерных и парниковых газов определен методом газовой хроматографии. Проведено сравнение содержания газа во льдах и мерзлом торфе с содержанием газа в атмосфрере, значениями растворимости газа в воде. Выполнен корреляционный анализ содержания газов в распространенных типах подземных льдов и мерзлом торфе.

Результаты. Установлено, что газ, заключенный в подземных льдах и мерзлом торфье, по относительному содержанию азота и кислорода близок к атмосфрерному. В пробах выявлены большие вариации содержания метана от 4 до $1,7 \cdot 10^{4} \mathrm{ppmV}$ u углекислого газа от 7 до 2,7 $10^{3} \mathrm{ppmV}$, которые связаны с различными условиями для продуцирования и накопления парниковых газов в мерзлой толще. Установлено преобладание содержаний углекислого газа над метаном в сегрегационных и повторно-жильных льдах. Максимальные концентрации метана (om 1,1 103 до 1,7·104 ppmV) обнаружены в сегрегационномиграционных льдах бугра пучения и клиновидных льдах. Избыток метана в приповерхностных сегрегационно-миграционных льдах связан с его накоплением в оттаивавших отложениях таликов и последующим льдовыделением при промерзании в замкнутой системе. Установлены высокие содержания углекислого газа (до 1,1 1 103 ppmV) и метана (до 222 рpmV) в сегрегационном льду в торфре, их источником является органическое вещество, разлагающееся в переменных аэробных и анаэробных условиях под действием бактерий, поэтому торффяники являются значительным источником поступления углекислого газа в атмосферу. Проведена оценка воспроизводимости и сопоставимости методов термовакуумной дегазации и «headspace» при исследовании льдов и мерзлых отложений в разрезе торффяника в районе с. Газ-Сале. Установлено, что кониентрации метана при опробовании методом «headspace» завышены в 3-70 раз по сравнению с величинами, определенными методом термовакуумной дегазации. Это обусловлено низкой растворимостью метана и преобладанием его в пузырьках, а углекисльй газ и часть кислорода остаются растворены в воде и не переходят в пробу газа. Следовательно, данных о содержании газа, определенного методом «headspace», недостаточно для оценки объемов эмиссии парниковых газов, поскольку эти величины характеризуют состав нерастворенного газа. Метод термовакуумной дегазации позволяет рассчитать и оценить объемы поступления газов из оттаивающих мерзлых толщ.

\section{Ключевые слова:}

Парниковые газы, подземные льды, биогенный метан, газонасыщенные породы, метод термовакуумной дегазации, метод headspace.

\section{Введение}

Глобальные изменения климата и их прогноз тесно связаны с изучением антропогенной и естествен- ной эмиссии парниковых газов в атмосферу. По данным о составе газов, заключенных в ледниках, реконструируют состав атмосферы во время их формиро- 
вания, делают вывод о повышенных концентрациях метана и углекислого газа в настоящее время и прогнозируют изменения климата [1-3].

Поступление парниковых газов в атмосферу из акватории морей Арктической зоны связывают с антропогенными, биогенными и геологическим источниками, в т. ч. с разложением газовых гидратов метана на дне морей $[4,5]$. Установлено, что газ в морском однолетнем льду [6] весьма близок к составу атмосферы. Образование биогенного газа в морских отложениях является результатом взаимодействия микроорганизмов со средой [7]:

1) в условиях, где присутствует достаточно кислорода, при аэробном дыхании происходит окисление углеводов $\mathrm{CH}_{2} \mathrm{O}+\mathrm{O}_{2} \rightarrow \mathrm{CO}_{2}+\mathrm{H}_{2} \mathrm{O}$;

2) при недостатке кислорода происходит восстановление нитратов, железа и марганца: $\mathrm{NO}_{3} \rightarrow \mathrm{N}_{2}$; $\mathrm{Fe}^{3+} \rightarrow \mathrm{Fe}^{2+} ; \mathrm{Mn}^{4+} \rightarrow \mathrm{Mn}^{2+}$

3) в условиях полного отсутствия кислорода доминирующей формой дыхания становится восстановление сульфата: $2 \mathrm{CH}_{2} \mathrm{O}+\mathrm{SO}_{4}{ }^{2-} \rightarrow \mathrm{H}_{2} \mathrm{~S}+2 \mathrm{HCO}_{3}{ }^{-}$;

4) когда сульфаты истощаются, в результате анаэробного окисления органического вещества образуется метан в процессах $\mathrm{CO}_{2}+4 \mathrm{H}_{2} \rightarrow \mathrm{CH}_{4}+\mathrm{CO}_{2}$ и $\mathrm{CH}_{3} \mathrm{COOH} \rightarrow \mathrm{CH}_{4}+\mathrm{CO}_{2}$ [4]. Газ генерируется в анаэробных условиях в отложениях без сульфатов ферментативными бактериями, ацетогенными бактериями и группой архей, называемых метаногенами [8].

Известно, что в льдистых мерзлых породах заключены значительные запасы углерода [9]. Термокарстовые озера в зоне распространения многолетнемерзлых пород являются источником поступления метана в атмосферу вследствие поступления органических веществ из оттаивающих отложений $[10,11]$ Объем поступления биогенного газа в атмосферу при таянии мерзлых льдистых толщ недостаточно изучен [12].

Большинство исследований газовых включений во льдах посвящено изотопии углерода, кислорода и водорода $[13,14]$. В последние годы устанавливают распределение и содержание газов в наиболее распространенных подземных повторно-жильных и пластовых льдах, мерзлых отложениях и связывают преобладание метана с биогенным происхождением в мерзлоте и продуцированием в таликах [13-17].

А.А. Архангелов и Е.В. Новгородова [18] определили состав газа, извлеченного методом «headspace» из сегрегационных, инъекционных и ледниковых льдов. Они использовали состав газов как метод для определения генетического типа льда. Авторы показали, что для инъекционных льдов характерны высокие концентрации $\mathrm{CH}_{4}(27,5 \%$ в составе газовых пузырьков), для сегрегационных и ледниковых льдов состав газа был близок к атмосферному.

А.К. Васильчук и Ю.К. Васильчук [19] изучили состав газов $\left(\mathrm{H}_{2}, \mathrm{O}_{2}, \mathrm{~N}_{2}, \mathrm{CO}_{2}, \mathrm{CH}_{4}\right)$ в повторножильных льдах, торфе и воде озера термокарстового понижения с полигональным торфяником в Сеймчано-Буюдинской впадине Якутии. Для сбора минимально достаточного объема газа требовалось 2-3 дня на один образец торфа, для получения нужного объёма газов изо льда - несколько часов. Исследователи утверждают, что высокие концентрации метана являются результатом метаногенеза.

А.А. Васильев и соавторы [13] методом «headspace» и динамическим методом определили концентрации метана в повторно-жильных льдах (100-700 ppmV) и пластовых льдах (до 10000 ppmV) в мерзлой толще м. Марре-Сале. И.Д. Стрелецкая и соавторы [14] дополнили исследования данными о содержании метана в повторно-жильных (до $272 \mathrm{ppmV}$ ) и пластовых льдах (до 1588 ppmV) Западного Ямала и Западного Таймыра (м. Сопочная Карга) и объяснили высокие концентрации метана в пластовых льдах м. Марре-Сале их внутригрунтовым происхождением миграцией метана из вмещающих отложений. Исследователи [15], используя метод «headspace», показали, что наибольшее содержание $\mathrm{CH}_{4}$ характерно для заболоченных ландшафтов - поверхности поймы p. Марре-Яха, эрозионных оврагов, логов и термокарстовых понижений.

П.Б. Семенов и соавторы использовали альтернативные методы извлечения газа в лабораторных условиях в атмосфере аргона и измерения содержаний свободного газа в повторно-жильных и пластовых льдах. Содержание свободного газа варьирует от 0,5 \% в пластовом льду до 5,5 \% в повторно-жильном льду, количество $\mathrm{CH}_{4}$ - от $0,05 \mathrm{ppmV}$ в повторно-жильном льду до 158 ppmV в пластовых льдах [20].

Высокие концентрации биогенных микроэлементов в таких природных объектах, как подземные льды, можно использовать в качестве биогеохимических индикаторов. Доказано, что повторно-жильные льды, как и ледники, наследуют химический состав атмосферных осадков и могут служить показателем загрязнения атмосферы и верхнего слоя почвы во время их формирования [21].

Информация о составе газа, заключенного в подземных льдах, может быть использована для реконструкции условий льдообразования - миграции газов и растворов из вмещающей геологической среды.

\section{Методы исследования, математической обработки и интерпретации химического состава}

Существуют разные методы извлечения газов из льдов. Метод «headspace» является наиболее доступным и популярным при определении содержания метана в мерзлых породах и льдах, оттаивание образца при этом производят в шприцах объемом 150 мл $[6,13,14,16,18]$. Метод «headspace» имеет ряд недостатков:

1) не позволяет отобрать достаточно большую пробу для химического анализа и парниковых и атмосферных газов;

2) не позволяет получить воспроизводимые условия дегазации (дегазацию производят в полевых условиях);

3) не позволяет определить количество газа, отобранного из объема пробы;

4) не учитывает различную растворимость газов в воде. 
Данные недостатки метода приводят к искажениям результатов и невозможности оценки объемов парниковых газов, заключенных в мерзлых породах и льдах.

Альтернативный метод извлечения газа из мерзлых пород и льда используют А.А. Васильев и соавторы [13] и И.Д. Стрелецкая и соавторы [14] - пробы измельчали в лабораторной мельнице при отрицательной температуре до фракции 25 мкм. Далее проводили дегазацию 200 г образца методом распыления воды и созданием вакуума. Недостатком такого метода является попадание атмосферных газов в лед при его измельчении.

Для анализа состава газа, заключенного в пластовых и повторно-жильных льдах, авторы [20] использовали монолиты льда массой 50 г. Для определения объема заключенного во льду газа один из цилиндров помещали в пластиковый пакет, откачивали воздух и оттаивали при $4{ }^{\circ} \mathrm{C}$; далее прокалывали пакет, погруженный в раствор $\mathrm{NaCl}$, и собирали газ в градуированный цилиндр. Для определения состава углеводородов монолит льда (50 г) помещали в ёмкость, заполненную аргоном, и встряхивали шейкером в течение 2 ч. Минусом данной методики является определение объема извлеченного газа и газового состава из разных проб льда.

В данном исследовании метод термовакуумной дегазации в лабораторных условиях с определением объёма газа во льду был использован как референтный. Для предотвращения диффузии газа монолиты льда были сохранены в мёрзлом состоянии и доставлены до лаборатории при отрицательной температуре за минимальное время. Пробоподготовка и анализ атмосферных и парниковых газов в монолитах мерзлых пород и льдов проведены в Учебно-научной лаборатории ТИУ канд. геол.-минерал. наук М.Д. Заватским. Газ извлекался на дегазационном приборе вакуумным насосом после термостатирования пробы в течение 20-30 мин при температуре $70-75^{\circ} \mathrm{C}$. Расчетная степень дегазации расплава - $98 \%$, так как при $80{ }^{\circ} \mathrm{C}$ коэффициент абсорбции для $\mathrm{N}_{2}, \mathrm{O}_{2}, \mathrm{CO}_{2}, \mathrm{CH}_{4}$ в воде не превышает 0,02 [22]. При дегазации были измерены объемы льда (190 до $\left.300 \mathrm{~cm}^{3}\right)$ и извлеченного газа (от 5 до $\left.25 \mathrm{~cm}^{3}\right)$, необходимые для расчета объемной доли газа в образце.

Во льдах и торфе определены содержания следующих газов: $\mathrm{N}_{2}, \mathrm{O}_{2}, \mathrm{CO}_{2}, \mathrm{H}_{2}, \mathrm{He}$, алканов и алкенов с числом углеродных атомов от 1 до 6 и их изомеров. Углеводороды определены на хроматографе «Хром5» с детектором ионизации в пламени, неорганические газы - на хроматографе «Газохром-2000» с детектором по теплопроводности для негорючих газов и термохимическим детектором для водорода.

Для интерпретации газового состава проведено сравнение содержания газа во льдах с содержанием газа в атмосфере [23] и со значениями растворимости газа в воде [24]. Проведен парный корреляционный анализ содержания газов во льдах в программе «Geochem Anomaly».

Для выявления метаногенеза в отложениях учитывались фоновые концентрации углеводородов: угле- водороды $\mathrm{C}_{1}-\mathrm{C}_{3}$ в морских отложениях содержаться в концентрации от 1 до $100 \mathrm{ppmV}$, углеводороды $\mathrm{C}_{3}-\mathrm{C}_{6}-$ от 0,01 до 2,0 ppmV. По составу углеводородных газов различают микробный или термогенных генезис газа [5].

Информации о количественных содержаниях углеводородов, углекислого газа, водорода, гелия в мерзлой толще в литературе мало [25]. Высокие содержания гелия (16-57 ppm) и водорода (12 ppm) в отложениях могут являться индикаторами наличия полезных ископаемых, разложения газогидратов, миграции газов по разломам [26].

\section{Район и объекты исследования}

Комплексные исследования многолетнемерзлых толщ в Карском регионе в 2017-2019 гг. включали изучение состава, строения отложений и геохимических особенностей подземного льда, поверхностных вод на ключевых участках. Исследования геохимических особенностей сегрегационных и повторножильных льдов проведены в районах м. Марре-Сале (Западный Ямал), с. Гыда (север п-ва Гыдан), с. ГазСале (Север Пур-Тазовского междуречья) (рис. 1). Районы исследований расположены в арктической зоне с продолжительной холодной зимой, коротким прохладным летом, небольшим количеством осадков 400 мм/год и преобладающим западным направлением ветров [27], что обеспечивает сплошное распространение многолетнемерзлых пород и подземных льдов.

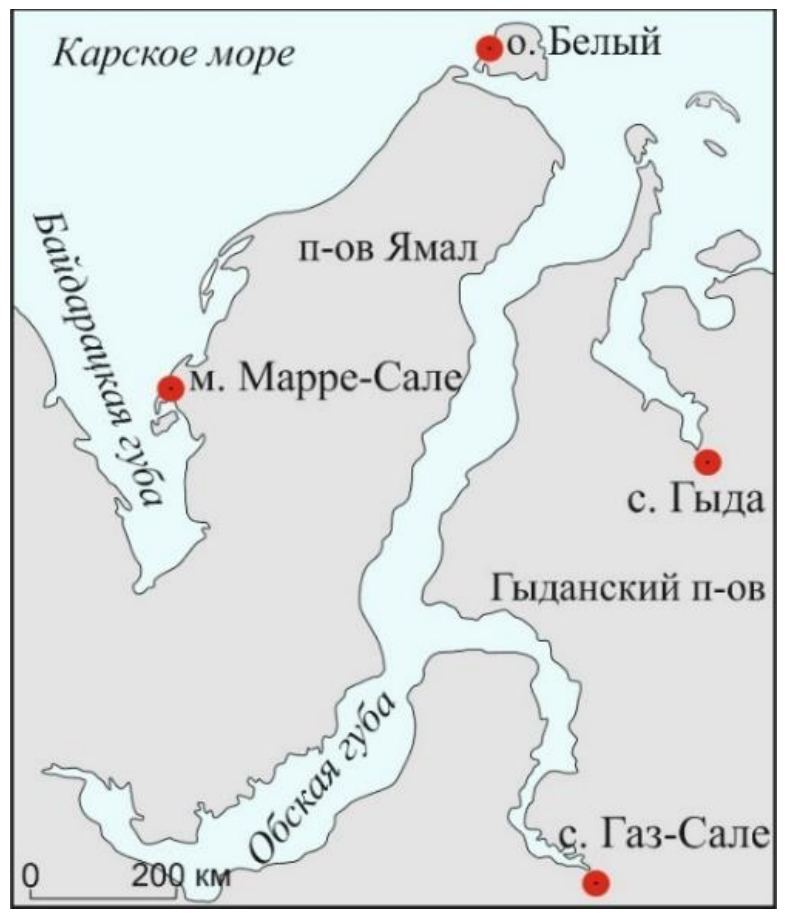

Рис. 1. Ключевые участки исследований газовых включений и геохимии многолетнемерзльх отложений $и$ подземных льдов на севере Западной Сибири

Fig. 1. Key areas of studying geochemistry of permafrost sediments and underground ice in the north of Western Siberia 
Объектами исследования являются подземные льды сегрегационного, повторно-жильного, миграционного и инъекционного генезиса, содержащие заключенные во льду парниковые и атмосферные газы (рис. 2):

На о. Белый, в пределах высокой лайды, затапливаемой водами Карского моря, изучено линзовидное ядро сегрегационно-миграционного льда торфяного бугра пучения [28].

В районе м. Марре-Сале, в пределах III морской равнины, в разрезе МС-1-19 и МС-19-19, изучены образцы сегрегационного льда из пластовых залежей субгоризонтальной и диапировой формы, которые залегают внизу разреза в таберальном комплексе марресальской свиты. Клиновидные сегрегационномиграционные льды внедряются в пластовые залежи и залегают вверху разреза в синкриогенных тонких песках и супесях. Мерзлая толща и льды с размывом перекрыты слоистыми песками и супесями [29].

На севере п-ва Гыдан, в пределах II надпойменной террасы, в разрезе В3, изучен линзовидный пластовый лёд мощностью 0,3 м, пересекающий повторно- жильный лед. Пласт залегает в мерзлой аллювиальной толще между слоями внизу - льдистого песка, вверху - суглинка с линзовидно-сетчатой криогенной текстурой. Ранее установлено, что линзовидный пластовый лед имеет инфильтрационно-сегрегационный генезис [30].

На севере Пур-Тазовского междуречья, в пределах III озёрно-аллювиальной равнины, в разрезе В8, изучен сингенетически промерзавший льдистый торфяник с массивной, корковой, шлировой, слоистой криогенными текстурами и повторно-жильным льдом [31].

В работе проанализирован состав атмосферных и парниковых газов, отобранных методом термовакуумной дегазации, в 14 монолитах льда и льдистого торфа: 1 - сегрегационно-миграционного льда, 2 - сегрегационно-миграционного клиновидного льда [29], 3 - сегрегационного текстурообразующего льда в торфе, 2 - термокарстово-полостного льда (термокарстово-пещерного льда по П.И. Шумскому) в составе жилы, 2 - повторно-жильного, 1 - сегрегационного пластового льда, 3 - инфильтрационно-сегрегационного льда.

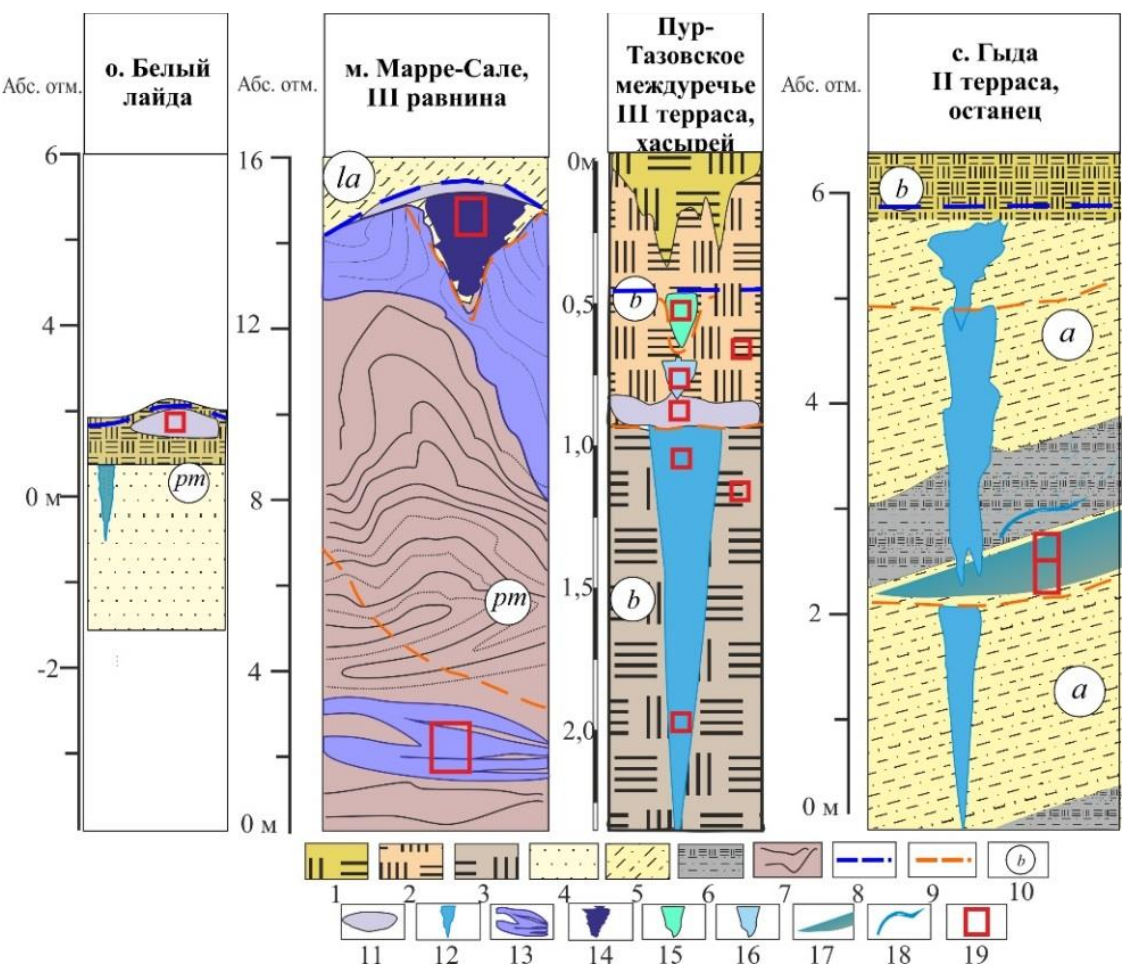

Рис. 2. Строение отложений и разновидности подземных льдов в голоценовых и верхнеплейсточеновых отложениях на севере Западной Сибири: 1 - мох свежий; 2 - торф криотурбированный с линзами и илирами льда; 3 - торф автохтонный синкриогенный; 4 - засоленные пески; 5 - пески, супеси; 6 - слоистые суглинки, супеси с растительными остатками; 7 - таберальный комплекс марресальской свиты: суглинки и супеси; 8 - граница сезонно-талого слоя; 9 - реликтовая граница сезонно-талого слоя; 10 - генезис отложений: $a$ - аллювиальный, $b$ - биогенный, la - озерно-аллювиальный, рт - прибрежно-морской; 11 - линзы льда; 12 - повторно-жильный лед; 13 - пластовый лед; 14 - сегрегационно-миграционный клиновидный лед; 15 - росток повторно-жильного льда; 16 - термокарстово-полостной лед; 17 -линзовидный пластовый лед; 18 - текстурообразующий лед; 19 - места отбора проб льда на геохимические исследования состава газа

Fig. 2. Structure of deposits and types of ground ice in Holocene and Upper Pleistocene sediments in the north of Western Siberia: 1 -moss; 2 - cryoturbated peat with ice lenses and belts; 3 - peat atochthonous syncryogenic; 4 - saline sands; 5 - sands, sandy loam; 6 -layered loam, sandy loam with plant remains; 7 - taberal complex of the Marre-Sale suite: loam and sandy loam; 8 - recent base of active layer; 9 - relict base of active layer; 10 - genesis of deposits: a alluvial, b-biogenic, la - lacustrine-alluvial, pm-coastal-marine; 11 -ice lenses, 12 - ice wedge; 13 - massive ice, 14 - segregated-migration wedge-shaped ice; 15 - young ice wedge; 16 - closed-cavity ice; 17 -lens-shaped massive ice; 18 -texture-forming ice; 19 - location of sampling points for geochemical studies of gas composition 

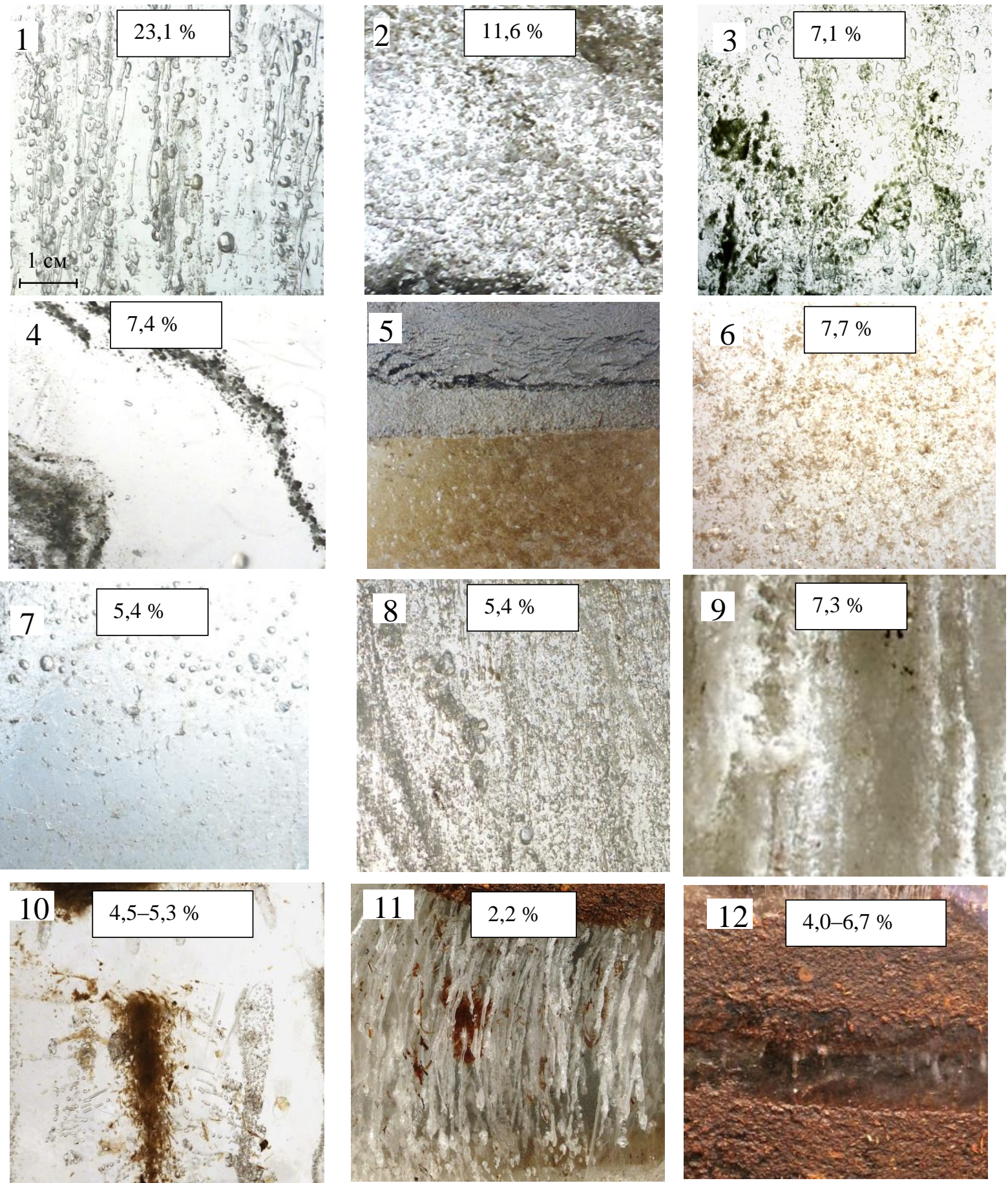

Pис. 3. Содержание пузырьков газа в разных типах льда в шлифах: 1 - сегрегационно-миграчионный лёд бугра пучения, о. Бельй; 2-4 - подземные льды разреза Марре-Сале 2019 г.: 2 - клиновидное тело сегрегационномиграчионного льда разреза МС-19-19; 3 - клиновидный лед разреза МС-1-19; 4 - пластовый сегрегационный лёд разреза 1-19; 5-7 - линзовидный инфильтрационно-сегрегационный пластовый лёд на севере Гыдана (разрез В3-18): 5 - верхний контакт с суглинком (содержание газа не определено); 6 - верхняя часть пласта, 7 - нижняя часть пласта; 8-12 - повторно-жильная система Пур-Тазовского междуречья (разрез В8-17): 8 - повторно-жильный лед; 9 - росток повторно-жильного льда; 10 - термокарстово-полостной лёд; 11 - илиры (пояски) инфильтрачионно-сегргачионного льда в торфе; 12 - торф с массивными и линзовидными криотекстурами. В процентах указано содержание газа от объема льда

Fig. 3. Gas bubbles content of different types of ice in thin sections: 1 - segregated-migration ice of heaving mound on Bely island; 2-4 - underground ice of the Marre-Sale section in 2019: 2 - segregated-migration wedge-shaped ice in MS-19-19 section; 3 - wedge-shaped ice in MS-1-19 section; 4 - segregated massive ice in MS-1-19 section; 5-7 - infiltrated-segregated ice lens in the north of Gydan (section B3-18): 5 - upper contact with loam; 6 - upper part of the massive ice, 7 - lower part of the massive ice; 8-12 - ice wedge polygon system of the Pur-Taz interfluve (section V8-17): 8 -ice wedge; 9 - young wedge ice; 10 - closed-cavity ice; 11 -ice belts of infiltrated-segregated ice in peat; 12 - peat with massive and lens cryotextures. The gas content in relation to the ice volume is indicated (\%) 
Изученные типы подземных льдов содержат многочисленные пузырьки газов, которые отличаются по форме, размерам, ориентировке, количеству и соотношениям с органическими, минеральными включениями (рис. 3). Наличие крупных пузырьков обусловлено плохо растворимыми газами, в основном метаном. Если газ хорошо растворим, как, например, углекислый газ, он не будет формировать крупных пузырьков до достижения предела растворимости (1700 ppmV) [22].

\section{Результаты и их обсуждение}

При анализе состава газов, извлеченных методом термовакуумной дегазаџии из подземных льдов и мерзлых отложений, выявлены общие особенности. Количество $\mathrm{N}_{2}$ составляет от 75 до $86 \%$ и $\mathrm{O}_{2}$ от 12 до $20 \%$ от объема всех газов, такой состав близок к составу атмосферного воздуха (рис. 4). Объемная доля извлеченного газа варьирует от 2 до $23 \%$ от объема льда (табл. 1).

Количество $\mathrm{CH}_{4}$ варьирует от 0,01 до 3,8 \% (от 4,4 до $16967 \mathrm{ppmV}$ в объеме льда). Только в четырех пробах (сегрегационного льда в торфе и сегрегационно-миграционных льдов) выявлены концентрации $\mathrm{CH}_{4}$ выше фоновых значений (>100 ppmV; до 7,4\% от состава газа). Полученные результаты значительно отличаются от содержаний $\mathrm{CH}_{4}$ в газовых пузырях, выделяющихся из донных отложений термокарстовых озер на Аляске, которые достигают 68 \% [10]. Газы, связанные с геологическим строением и разгрузкой флюидов, например, из донных отложений Байкала, отличаются колебаниями $\mathrm{CH}_{4}$ от 0 до $75 \%$ и $\mathrm{CO}_{2}$ от 0 до $7 \%$ [24].

Содержание $\mathrm{CO}_{2}$ варьирует от 0,01 от $1,17 \%$ (от 7 до $2692 \mathrm{ppmV}$ ). Минимальные значения обнаружены в термокарстово-полостном льду, который сформирован из вод атмосферных осадков, максимальные значения обнаружены в сегрегационно-миграционном льду в торфе. Эти результаты хорошо сопоставимы с данными по эмиссии значительных объемов $\mathrm{CO}_{2}$ в атмосферу из торфяников [32].

Содержание $\mathrm{H}_{2}$ варьирует от 1 до $14 \mathrm{ppmV}$, максимальное содержание обнаружено в сегрегационном льду в торфе, это связано с медленным разложением органики в восстановительных условиях.

Содержание углеводородов $\mathrm{C}_{2}-\mathrm{C}_{6}$ варьирует от 0,04 до $1,35 \mathrm{ppmV}$, такие низкие концентрации принято считать фоновыми. Количество $\mathrm{CH}_{4}$ от суммы углеводородов слабо варьирует и в среднем равно $99 \%$, это является показателем биогенного происхождения и отсутствия поступления газа по разломам [5].

Обнаружены следовые концентрации гелия (до 1,5 $\mathrm{ppmV)} \mathrm{в} \mathrm{инфильтрационно-сегрегационном} \mathrm{льду} \mathrm{и} \mathrm{в}$ ростке повторно-жильного льда, вероятно, источником гелия были воды атмосферных осадков, сформировавшие льды.

При проведении парного корреляционного анализа установлены корреляции объема газа, извлеченного из льда, и содержаний $\mathrm{CH}_{4}, \mathrm{H}_{2}$, углеводородов $\mathrm{C}_{2}-\mathrm{C}_{6}$. Из этого следует, что эти газы имеют общий механизм накопления в подземных льдах.
Вышеизложенные особенности химического состава газа в подземных льдах Западной Сибири указывают на: 1) отсутствие поступления глубинных газов при формировании льда; 2) продуцирование $\mathrm{CO}_{2}$ в органических горизонтах отложений; 3) миграцию $\mathrm{CH}_{4}$ в подземные льды при протаивании прибрежноморских отложений.

На рис. 4 видно, что содержания $\mathrm{CO}_{2}$ и $\mathrm{CH}_{4}$ сильно варьируют, при этом в сегрегационно-миграционных льдах преобладает $\mathrm{CH}_{4}$, а в сегрегационных и повторно-жильных льдах преобладает $\mathrm{CO}_{2}$.

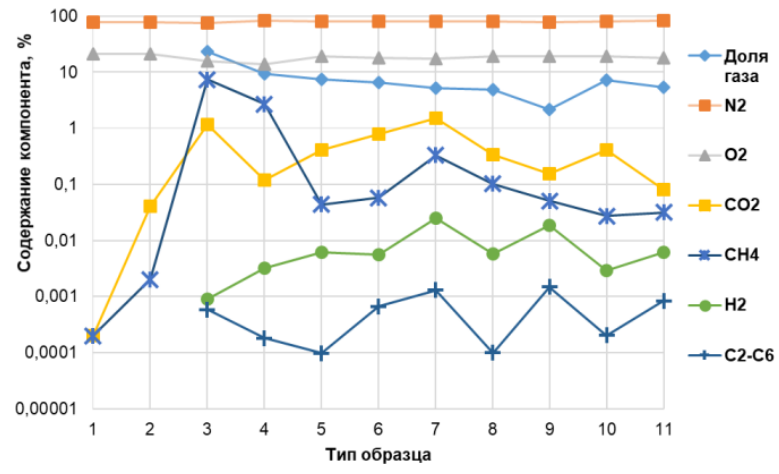

Pис. 4. Содержание газа в атмосферном воздухе (1) [23], в леднике Купола Вавилова (2) [18], подземных льдах на о. Бельй (3 - сегрегачионномиграционный лед), на западном Ямале (4 - сегрегаиионно-миграиионный клиновидный лед, 5 - сегрегачионный пластовый лед), на севере $n$ ва Гылан (6 - инфильтрационно-сегрегационный лед), на Севере Пур-Тазовского междуречья (7 - сегрегационный лед в торфе, 8 - термокарстово-полостной лед, 9 - инфильтрачионносегрегачионный лед, 10 - росток повторножильного льда, 11 - повторно-жильный лед)

Fig. 4. Gas content in atmospheric air (1) [23], glacial ice Vavilov's Dome (2) [18], underground ice on the Bely island (3 - segregated-migration ice), in western Yamal (4 - segregated-migration wedgeshaped ice, 5 - segregated massive ice), in the north of the Gydan Peninsula (6 - infiltrated-segregated ice), in the North of the Pur-Taz interfluve (7 segregated ice in peat, 8 - closed-cavity ice, $9-$ infiltrated-segregated ice, 10 - young ice wedge, 11 - ice wedge)

Различия в газонасыщенности льда и в распределении химического состава газа можно объяснить разными генетическими типами льда. На лайде о. Белый под торфом вскрыт сегрегационномиграционный лед, прозрачный с включениями торфа. Лед имеет множество крупных пузырьков газа (23\%). В составе газа значительная часть приходится на $\mathrm{CH}_{4}$ $(7,4 \%)$ и $\mathrm{CO}_{2}(1,2 \%$, рис. $5, a)$. Концентрации этих газов превышают предел растворимости в воде (табл. 1).

В работе [28] были отмечены инъекции песка в перекрывающих отложениях, следовательно, накопление газов в осадках происходило при неравномерном протаивании отложений при заливании морскими водами. Протаивание могло сопровождаться миграцией $\mathrm{CH}_{4}$ и $\mathrm{CO}_{2}$ в ядро небольшого многолетнего 
бугра пучения из прибрежно-морских отложений. Высокие концентрации обусловлены поступлением газов из талых прибрежно-морских осадков при фор- мировании ядра бугра пучения, промерзанием в замкнутом объеме и защемлением $\mathrm{CH}_{4}$ и $\mathrm{CO}_{2}$ между растущими кристаллами льда.

Таблица 1. Состав газа, заключенного в подземных льдах на севере Западной Сибири

Table 1. Composition of entrapped gas in underground ice on the north of Western Siberia

\begin{tabular}{|c|c|c|c|c|c|c|c|c|c|c|c|c|c|c|}
\hline \multirow{2}{*}{$\begin{array}{c}\text { Район } \\
\text { исследования, } \\
\text { разрез } \\
\text { Study area, } \\
\text { section }\end{array}$} & \multirow[t]{2}{*}{$\begin{array}{l}\text { Тип образца } \\
\text { Sample type }\end{array}$} & \multirow{2}{*}{$\begin{array}{c}\begin{array}{c}\text { Глубина } \\
\text { Depth }\end{array} \\
\text { м }\end{array}$} & \multirow{2}{*}{\begin{tabular}{|c|} 
Доля \\
газа \\
Gas \\
share
\end{tabular}} & \multirow{2}{*}{\multicolumn{2}{|c|}{\begin{tabular}{l|l}
$\mathrm{N}_{2}$ & $\mathrm{O}_{2}$ \\
& \\
$\%$
\end{tabular}}} & \multicolumn{2}{|c|}{$\mathrm{CH}_{4}$} & \multicolumn{2}{|c|}{$\mathrm{CO}_{2}$} & \multicolumn{2}{|c|}{$\mathrm{H}_{2}$} & \multicolumn{2}{|c|}{$\begin{array}{c}\text { Углеводороды } \\
\text { Hydrocarbons } \\
\mathrm{C}_{2}-\mathrm{C}_{6}\end{array}$} & \multirow[t]{2}{*}{$\mathrm{He}$} \\
\hline & & & & & & ppmV & $\%$ & $\begin{array}{c}\mathrm{ppm} \\
\mathrm{V}\end{array}$ & $\%$ & ppmV & $\%$ & ppmV & $\%$ & \\
\hline \multicolumn{2}{|c|}{$\begin{array}{l}\text { Атмосферный воздух } \\
\text { Atmospheric air [23] }\end{array}$} & - & - & 78,1 & 21,0 & 2 & $2 \cdot 10^{-4}$ & 300 & 0,03 & 0,5 & $5 \cdot 10^{-5}$ & - & - & $5 \cdot 10^{-4}$ \\
\hline \multicolumn{2}{|c|}{$\begin{array}{l}\text { Растворимость при } 0{ }^{\circ} \mathrm{C} \\
\text { Solubility at } 0{ }^{\circ} \mathrm{C}[22]\end{array}$} & - & - & - & - & 56 & - & 1713 & - & 21 & - & \begin{tabular}{|c}
226 \\
(этилен \\
ethylene)
\end{tabular} & - & - \\
\hline $\begin{array}{l}\text { Купол Вавилова } \\
\text { Vavilov's Dome }\end{array}$ & $\begin{array}{l}\text { Ледниковый лед } \\
\text { Glacial ice [18] }\end{array}$ & - & - & 78,1 & 20,7 & - & 0,002 & - & 0,04 & - & $<0,01$ & - & - & $5,2 \cdot 10^{-4}$ \\
\hline $\begin{array}{l}\text { o. Белый } \\
\text { Bely island }\end{array}$ & $\begin{array}{l}\text { Сегрегационно- } \\
\text { миграционный лед } \\
\text { Segregated- } \\
\text { migration ice }\end{array}$ & 0,4 & 23,1 & 74,9 & 15,7 & 16967 & 7,35 & 2692 & 1,17 & 2,1 & 0,001 & 1,35 & $5,8 \cdot 10^{-4}$ & $<5 \cdot 10^{-4}$ \\
\hline $\begin{array}{l}\text { м. Мappe- } \\
\text { Сале, MC-19-19 } \\
\text { Marre-Sale Cape, } \\
\text { MS-19-19 }\end{array}$ & \multirow{2}{*}{$\begin{array}{l}\text { Сегрегационно- } \\
\text { миграционный } \\
\text { клиновидный лед } \\
\text { Segregated-migration } \\
\text { wedge-shaped ice }\end{array}$} & $1,75-1,90$ & 11,6 & $|78,4|$ & 15,8 & 4401 & 3,78 & 51,6 & 0,01 & 2,4 & 0,002 & 0,21 & $1,8 \cdot 10^{-4}$ & $<5 \cdot 10^{-4}$ \\
\hline $\begin{array}{l}\text { MC-1-19 } \\
\text { MS-19-19 }\end{array}$ & & $3,60-3,80$ & 7,1 & 85,7 & 11,7 & 1111 & 1,56 & 137 & 0,01 & 3,1 & 0,004 & 0,13 & $1,8 \cdot 10^{-4}$ & $<5 \cdot 10^{-4}$ \\
\hline $\begin{array}{l}\text { м. Марре-Сале, } \\
\text { MC-1-19 } \\
\text { Marre-Sale Cape } \\
\text { MS-1-19 }\end{array}$ & $\begin{array}{l}\text { Сегрегационный } \\
\text { пластовый лед } \\
\text { Segregated massive i } \\
\text { ce }\end{array}$ & $13,0-13,5$ & 7,4 & 79,9 & 18,9 & 32,4 & 0,04 & 303 & 0,03 & 4,5 & 0,006 & 0,07 & $9,7 \cdot 10^{-5}$ & $<5 \cdot 10^{-4}$ \\
\hline \multirow{2}{*}{$\begin{array}{l}\text { с. Гыда, B3-2018 } \\
\text { Gyda village, } \\
\text { V8-2018 }\end{array}$} & \multirow{2}{*}{$\begin{array}{l}\text { Инфильтрационно- } \\
\text { сегрегационный лед } \\
\text { Infiltrated-segregated } \\
\text { ice }\end{array}$} & $4,00-4,15$ & 7,7 & 79,3 & 18,3 & 4,4 & 0,01 & 541 & 0,70 & 1,1 & 0,001 & 0,47 & $6,0 \cdot 10^{-4}$ & 0,002 \\
\hline & & $4,15-4,30$ & 5,4 & 79,9 & 17,6 & 58,6 & 0,11 & 472 & 0,88 & 5,1 & 0,010 & 0,38 & $7,2 \cdot 10^{-4}$ & $<5 \cdot 10^{-4}$ \\
\hline \multirow{8}{*}{$\begin{array}{l}\text { c. Газ-Сале, } \\
\text { B8-2018 } \\
\text { Gas-Sale village, } \\
\text { V8-2018 }\end{array}$} & \multirow{3}{*}{$\begin{array}{l}\text { Сегрегацион- } \\
\text { ный лед в торфе } \\
\text { Segregated ice in } \\
\text { peat }\end{array}$} & $0,50-0,60$ & 6,7 & 79,9 & 17,2 & 185 & 0,28 & 1056 & 0,11 & 7,3 & 0,011 & 0,28 & $4,2 \cdot 10^{-4}$ & $<5 \cdot 10^{-4}$ \\
\hline & & \begin{tabular}{|l|}
$1,15-1,45$ \\
\end{tabular} & 4,0 & 80,0 & 17,0 & 98 & 0,25 & 475 & 0,05 & 14,2 & 0,035 & 1,11 & $2,8 \cdot 10^{-3}$ & $<5 \cdot 10^{-4}$ \\
\hline & & $1,40-1,60$ & 4,8 & 79,9 & 17,8 & 222 & 0,47 & 838 & 0,08 & 13,5 & 0,028 & 0,34 & $7,1 \cdot 10^{-4}$ & $<5 \cdot 10^{-4}$ \\
\hline & \multirow{2}{*}{$\begin{array}{l}\text { Термокарстово- } \\
\text { полостной лед } \\
\text { Closed-cavity ice }\end{array}$} & $0,55-0,70$ & 5,3 & 78,7 & 19,8 & 19,7 & 0,04 & 7,1 & 0,01 & 3,7 & 0,007 & 0,04 & $7,6 \cdot 10^{-5}$ & $<5 \cdot 10^{-4}$ \\
\hline & & $0,55-0,60$ & 4,5 & 79,7 & 18,2 & 75,3 & 0,17 & 295 & 0,65 & 2,0 & 0,005 & 0,06 & $1,2 \cdot 10^{-4}$ & $<5 \cdot 10^{-4}$ \\
\hline & \begin{tabular}{|l|} 
Инфильтрационно- \\
сегрегационный лед \\
Infiltrated- \\
segregated ice \\
\end{tabular} & $0,60-0,70$ & 2,2 & 78,4 & 19,4 & 11,1 & 0,05 & 33,9 & 0,16 & 4,1 & 0,019 & 0,32 & $1,5 \cdot 10^{-3}$ & $<5 \cdot 10^{-4}$ \\
\hline & $\begin{array}{l}\text { Росток повторно- } \\
\text { жильного льда } \\
\text { Young ice wedge } \\
\end{array}$ & $0,5-0,7$ & 7,3 & 79,7 & 19,0 & 19,9 & 0,03 & 302 & 0,42 & 2,1 & 0,003 & 0,15 & $2,0 \cdot 10^{-4}$ & 0,002 \\
\hline & \begin{tabular}{|l|} 
Повторно-жильный \\
лед \\
Ice wedge \\
\end{tabular} & $1,15-1,45$ & 5,4 & $81,8 \mid$ & 17,6 & 17,0 & 0,03 & 43,4 & 0,08 & 3,3 & 0,006 & 0,45 & $8,4 \cdot 10^{-4}$ & $<5 \cdot 10^{-4}$ \\
\hline \multirow{2}{*}{$\begin{array}{l}\text { «едяная гора» } \\
\text { «Ісе Mountain» } \\
\text { [18] }\end{array}$} & $\begin{array}{l}\text { Сегрегационный } \\
\text { лед } \\
\text { Segregated ice }\end{array}$ & - & - & 76,4 & 21,6 & - & 0,026 & - & 0,00 & - & 0,20 & - & - & $6,9 \cdot 10^{-4}$ \\
\hline & $\begin{array}{l}\text { Инъекционный } \\
\text { Injection ice }\end{array}$ & - & - & 67,5 & 4,01 & - & 27,5 & - & 0,07 & - & 0,18 & - & - & $5,1 \cdot 10^{-4}$ \\
\hline \multirow{3}{*}{$\begin{array}{l}\text { Верхнее течение } \\
\text { p. Колыма } \\
\text { Upper course of } \\
\text { the Kolyma river } \\
\text { [19] }\end{array}$} & Topф/Peat & 1,8 & - & 33,2 & 0,8 & - & 15,4 & - & 6,14 & - & \begin{tabular}{|l|}
43,4 \\
\end{tabular} & - & - & - \\
\hline & $\begin{array}{l}\text { Озерная вода } \\
\text { Lake water } \\
\end{array}$ & 1,8 & - & 55,2 & 0,5 & - & 10,6 & - & 12,4 & - & 21,4 & - & - & - \\
\hline & $\begin{array}{l}\text { Повторно-жильный } \\
\text { лед } \\
\text { Ice wedge } \\
\end{array}$ & - & - & 74,5 & 11,5 & - & 0,06 & - & 10,2 & - & 3,44 & - & - & - \\
\hline
\end{tabular}


В районе м. Марре-Сале лед клиновидной формы с прослоями грунта имеет сегрегационно-миграционный генезис [29]. В клиновидных льдах обнаружены невысокие концентрации $\mathrm{O}_{2}$ и $\mathrm{CO}_{2}$ (ниже атмосферных значений), но выявлены высокие концентрации $\mathrm{CH}_{4}(2-4 \%)$.

Такой состав газов и высокая газонасыщенность (до 11,6 \%) связаны с условиями формирования этих льдов. Авторы полагают, что клиновидные льды являются частично вытаявшими и размытыми сверху ядрами бугров пучения. Бугры пучения формировались вблизи поверхности при промерзании таликов крупных термоэрозионных колодцев, просадок и промоин в кровле пластовых залежей. Эти полости заполнены продуктами оттаивания мерзлых пород отложениями таберального комплекса, растворами и газами из сегрегационных, сегрегационноинъекционных льдов. Всестороннее промерзание замкнутой полости привело к накоплению $\mathrm{CH}_{4}$ и $\mathrm{CO}_{2}$ в ледяных ядрах бугров. Ранее в районе м. Марре-Сале при бурении скважин было зафиксировано [33] поступление метана в атмосферу из мерзлой толщи с пластовыми льдами.

Пластовый лед сегрегационного генезиса с прослоями грунта имеет состав газов близкий к составу термокарстово-полостного льда - низкие концентрации парниковых газов и углеводородов. Следовательно, отсутствовали условия для накопления $\mathrm{CH}_{4}$ и $\mathrm{CO}_{2}$. Сегрегационные пластовые льды имеют низкие содержания $\mathrm{CH}_{4}$ и других углеводородов и относительно высокие содержания $\mathrm{CO}_{2}$. Такой состав обусловлен отсутствием условий для накопления $\mathrm{CH}_{4}$ и $\mathrm{CO}_{2}-$ промерзанием разуплотненных прибрежно-морских водонасыщенных осадков. При формировании сегрегационного льда могла происходить дифференциация газового состава - нерастворенный $\mathrm{CH}_{4}$ поступал в верхнюю часть залежи льда или в атмосферу, а хорошо растворимый углекислый газ был включен в состав льда.

Проведено сравнение с результатами анализа $\mathrm{CH}_{4}$ методом «headspace» в отложениях и льдах в районе м. Марре-Сале. Авторы [15] приводят результаты о содержании $\mathrm{CH}_{4}$ до $13000 \mathrm{ppmV}$ в верхнем горизонте многолетней мерзлоты (болота, пойма реки), опробованных до глубины 2 м. Эти данные сопоставимы с содержанием метана в клиновидных льдах сегрегационно-миграционного генезиса.

По данным [14] содержание метана в повторножильных льдах варьирует от 2 до $1100 \mathrm{ppmV}$. Эти жилы залегают в отложениях на высоте 15-30 м над уровнем моря и не имеют засоления. Высокие концентрации $\mathrm{CH}_{4}$ в жилах могут быть связаны как с участием в их составе сегрегационных льдов, сформированных из внутригрунтовых вод, так и с результатом опробования генетически различных, но похожих по форме, типов льда - повторно-жильных и сегрегационно-миграционных клиновидных.

Линзовидный пластовый лёд в районе с. Гыда имеет инфильтрационно-сегрегационный генезис и сформирован из озерных вод таликов [30]. Содержание $\mathrm{CH}_{4}, \mathrm{H}_{2}$ значительно выше в нижней части льда, чем в верхней. Лёд имеет близкую объемную долю газа $(7,7$ и $5,4 \%)$ в верхней и нижней части (табл. 1$)$. В верхней части льда обнаружены следовые содержания $\mathrm{He}(1 \mathrm{ppmV})$. Содержание $\mathrm{CO}_{2}$ во льду в 20 раз выше, чем в воздухе, что связано с увеличением растворимости углекислого газа с понижением температуры. Для азота и кислорода зависимость растворимости с понижением температуры менее выражена. Содержание $\mathrm{CH}_{4}, \mathrm{CO}_{2}, \mathrm{H}_{2}$ не превышает предела растворимости этих газов в воде, следовательно, формирование льда было безнапорным и не сопровождалось насыщением льда газом из протаивающих отложений. Однако при медленном промерзании произошло перераспределение газа во льду.

Медленное безнапорное промерзание подтверждается химическим составом линзовидного пластового льда. Лед по содержанию солей ультрапресный, ионный состав сформирован в континентальных условиях. Соотношения ионов в текстурообразующих и линзовидных пластовых льдах очень близкое. Текстурообразующий лёд имеет засоление континентального типа. Высокие концентрации ионов и микроэлементов являются результатом медленного промерзания неглубокого талика, которое сопровождалось перераспределением химического состава и вытеснением солей в остаточный (поровый) раствор во вмещающих отложениях [30].

На рис. 5, $a$ показан состав извлеченного из льда газа по сравнению с газонасыщенностью образца льда и содержанием газов в воздухе и ледниковом льду. На рисунке видно, что $\mathrm{CH}_{4}$ занимает значимую часть от состава газов только в сегрегационно-миграционных льдах, а $\mathrm{CO}_{2}$ - в текстурообразующем льду в торфе.

На рис. 5,6 изображено содержание газов в подземных льдах с учетом содержания газа в объеме льда. На рисунке видно, что, помимо преобладающих $\mathrm{N}_{2}$ и $\mathrm{O}_{2}$, значимых концентрации во льдах достигают только $\mathrm{CH}_{4}$ и $\mathrm{CO}_{2}$. При этом в сегрегационномиграционных льдах преобладает $\mathrm{CH}_{4}$, что указывает на наличие условий для биогенного синтеза и накопления $\mathrm{CH}_{4}$ во время формирования льда. Минимальные содержания $\mathrm{CO}_{2}$ обнаружены в повторножильном льду и инфильтрационно-сегрегационном льду в торфе, такие содержания обусловлены атмосферным источником вод и быстрым промерзанием.

Текстурообразующий сегрегационный лед в криотурбированном торфе в районе с. Газ-Сале имеет высокие содержания $\mathrm{CH}_{4}, \mathrm{CO}_{2}, \mathrm{H}_{2}$. Содержание $\mathrm{CH}_{4}$ в торфе превышает предел его растворимости в воде, что является показателем его внутригрунтового генезиса. Более глубокий синкриогенный льдистый торф на глубине 2 м имеет большее содержание $\mathrm{CH}_{4}$ и меньшее $\mathrm{CO}_{2}$, чем торф с глубины $0,5-0,6$ м, что свидетельствует об отсутствии протаивания и меньшей аэрации синкриогенного торфа (табл. 1). Источником парниковых газов является органическое вещество, разлагающееся в переменных аэробных и анаэробных условиях под действием бактерий.

Термокарстово-полостной лед имеет в своем составе включения органики (рис. 3), но содержания $\mathrm{CH}_{4}$ и $\mathrm{CO}_{2}$ во льду незначительны, это связано с по- 
ступлением газа из торфа и миграцией из полости протаивания в атмосферу до промерзания.

Шлиры в инфильтрационно-сегрегационном льду с включениями торфа имеют малую газонасыщенность и

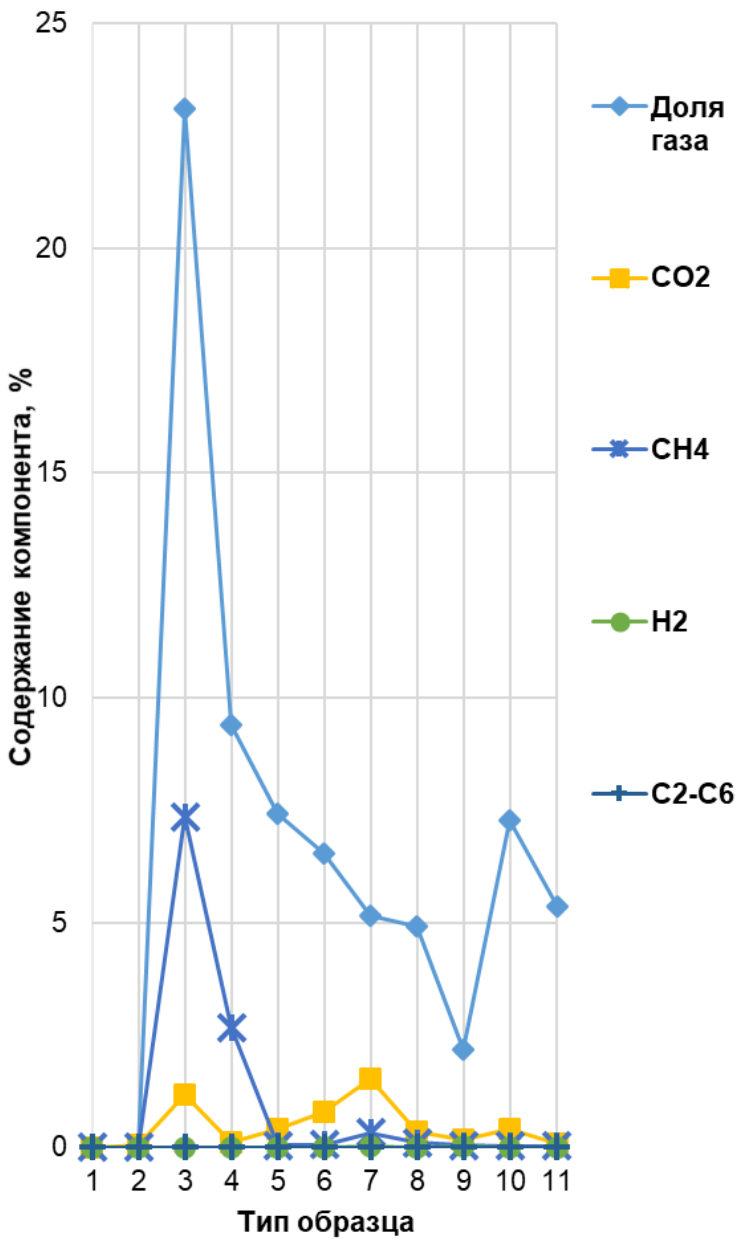

$a / a$ низкие концентрации парниковых газов. Лед имеет схожий состав с термокарстово-полостным льдом.

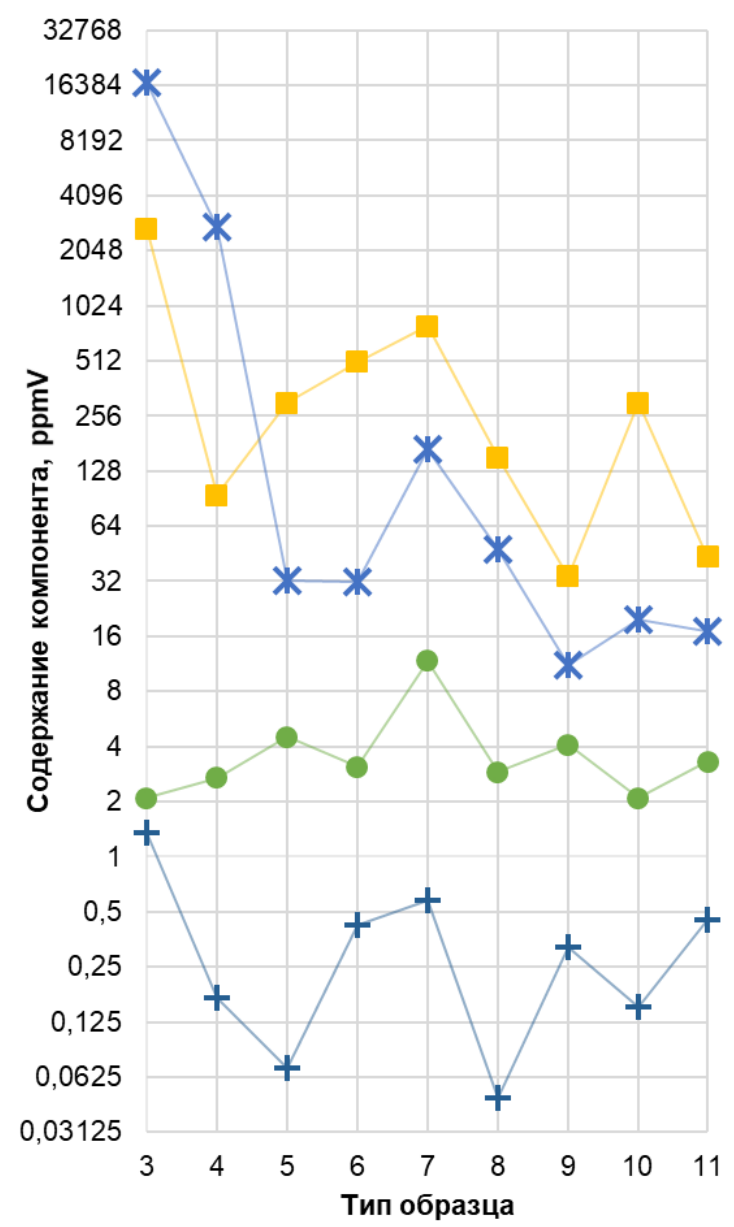

$\sigma / b$

Рис. 5. Содержание углекислого газа, углеводородов и водорода в подземных льдах в \% от объема анализируемого газа (а) и в миллионных долях от объема льда (б): 1 - атмосферный воздух [23]; 2 - ледник Купол Вавилова [18]; подземный лед на о. Бельй (3 - сегрегаџионно-миграиионный лед), на западном Ямале (4 - сегрегаиионно-миграционный клиновидный лед, 5 - сегрегационный пластовый лед), на севере п-ва Гыдан (6 - инфильтрационно-сегрегачионный лед), на Севере Пур-Тазовского междуречья (7 - сегрегачионный лед в торфе, 8 - термокарстово-полостной лед, 9 - инфильтрационно-сегрегационный лед, 10 - росток повторножильного льда, 11 - повторно-жильный лед)

Fig. 5. Content of carbon dioxide, hydrocarbons and hydrogen in underground ice in $\%$ of the analyzed gas volume (a) and in ppmV of the ice volume (b): 1-atmospheric air [23]; 2 - glacial ice of Vavilov's Dome [18]; underground ice on the Bely island (3 - segregated-migration ice), in western Yamal (4 - segregated-migration wedge-shaped ice, 5 - segregated massive ice), in the north of the Gydan Peninsula (6-infiltrated-segregated ice), in the North of the Pur-Taz interfluve (7 - segregated ice in peat, 8 - closed-cavity ice, 9 - infiltrated-segregated ice, 10 - young ice wedge, 11 - wedge ice)

В ростке повторно-жильного льда, имеющей незначительные включения органики, выявлены высокие концентрации $\mathrm{CO}_{2}$ относительно атмосферы, но обнаружен Не атмосферного генезиса. Высокие концентрации $\mathrm{CO}_{2}$ связаны с формированием жилы из талых снеговых вод, в которых содержание $\mathrm{CO}_{2}$ повышено вследствие увеличения его растворимости при низких температурах.

Повторно-жильный лед не имеет видимых включений органики в своем составе, в нем не обнаружены высокие концентрации парниковых газов и угле- водородов. Однако содержание $\mathrm{CH}_{4}$ и $\mathrm{CO}_{2}$ значительно выше, чем в атмосфере. Содержания $\mathrm{CH}_{4}$ до 20 $\mathrm{ppmV}$ обусловлены поступлением в жилу талых вод, насыщенных органическими веществами и газами из торфа. Состав льда жилы сильно отличается от состава газа в повторно-жильных льдах верхнего течения p. Колыма [19], в котором содержание $\mathrm{CO}_{2}$ достигало 10,6 \%. Различия обусловлены не только разными методами отбора проб газа, но и условиями залегания льдов. 
На основе полученных данных авторами проведен анализ и сравнение методов определения содержания газов во льдах. Проведена оценка воспроизводимости и сопоставимости методов термовакуумной дегазации и «headspace» при исследовании льдов и мерзлых от-

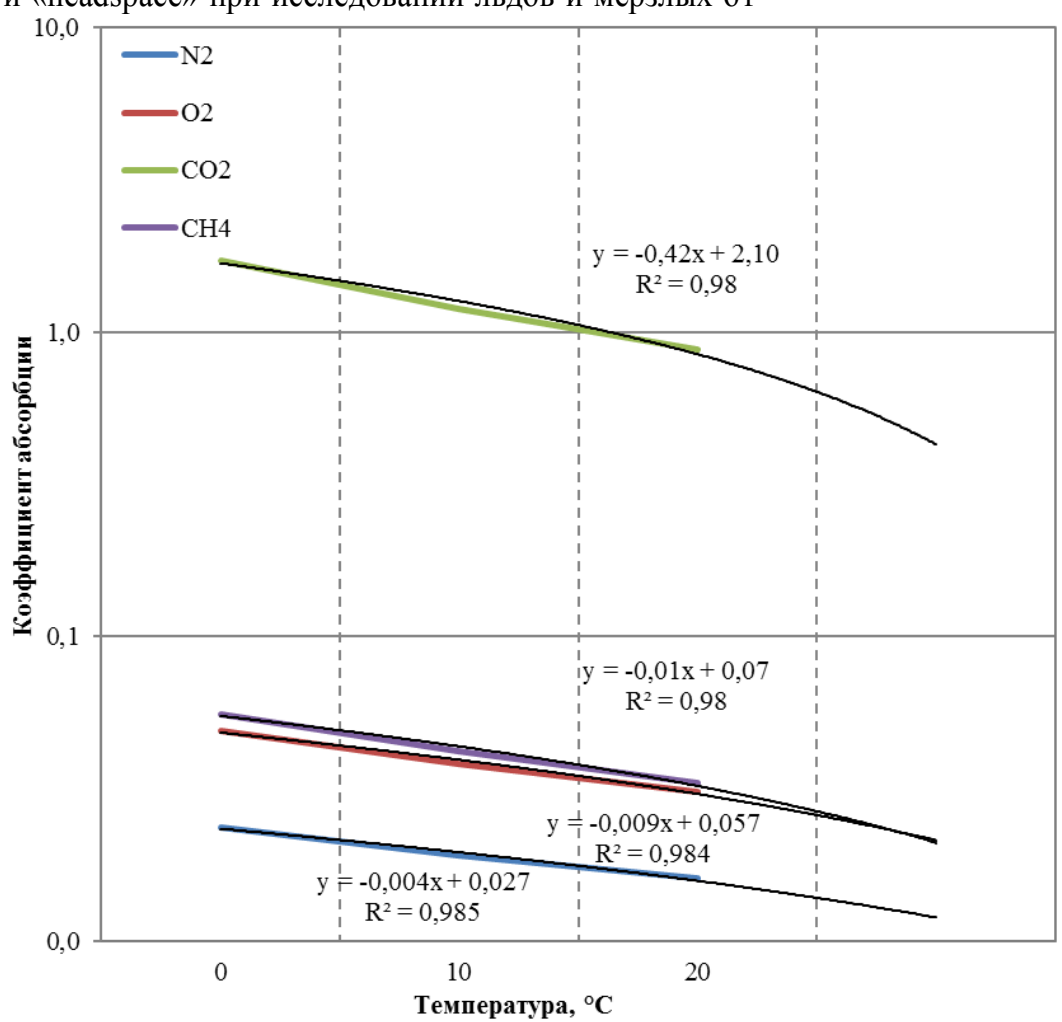

Pис. 6. Уменьшение растворимости газов в воде при повымении температуры [22]

Fig. 6. Reducing the solubility of gases in water with increasing temperature according to reference data [22]

При дальнейшем изучении растворимостей газов в воде установлено, что растворимость углекислого газа при $0{ }^{\circ} \mathrm{C}$ в 30-70, а при $20{ }^{\circ} \mathrm{C}$ в 30-55 раз выше, чем растворимость $\mathrm{N}_{2}, \mathrm{O}_{2}$ и $\mathrm{CH}_{4}$ (рис. 6).

Таблица 2. Содержание $\mathrm{CH}_{4}$ в подземных льдах и мерзлом торфе в районе с. Газ-Сале, $р p m V$

Table 2. $\mathrm{CH}_{4}$ content in ground ice and frozen peat in the area of Gas-Sale village, ppmV

\begin{tabular}{|c|c|c|c|}
\hline \multirow[b]{2}{*}{$\begin{array}{l}\text { Тип льда } \\
\text { Ice type }\end{array}$} & \multirow[b]{2}{*}{$\begin{array}{l}\text { Значение } \\
\text { Value }\end{array}$} & \multicolumn{2}{|c|}{$\begin{array}{l}\text { Метод дегазации } \\
\text { Degassing method }\end{array}$} \\
\hline & & $\begin{array}{c}\text { «headsp } \\
\text { ace» } \\
{[31]}\end{array}$ & $\begin{array}{c}\text { Термовакуумная } \\
\text { дегазация } \\
\text { Thermal vacuum } \\
\text { degassing }\end{array}$ \\
\hline $\begin{array}{c}\text { Сегрегационный лед в } \\
\text { торфе } \\
\text { Segregated ice in peat }\end{array}$ & $\begin{array}{l}\text { Мин/Min } \\
\text { Макс/Max }\end{array}$ & $\begin{array}{c}1832 \\
10509\end{array}$ & $\begin{array}{c}98 \\
222\end{array}$ \\
\hline $\begin{array}{l}\text { Термокарстово- } \\
\text { полостной лед } \\
\text { Closed-cavity ice }\end{array}$ & $\begin{array}{l}\text { Мин/Min } \\
\text { Макс/Max }\end{array}$ & 0 & $\begin{array}{l}19,7 \\
75,3\end{array}$ \\
\hline $\begin{array}{c}\text { Инфильтрационно- } \\
\text { сегрегационный лед } \\
\text { Infiltrated-segregated } \\
\text { ice }\end{array}$ & $\begin{array}{l}\text { Мин/Min } \\
\text { Макс/Max }\end{array}$ & $\begin{array}{c}90 \\
774\end{array}$ & 11,1 \\
\hline $\begin{array}{c}\text { Росток повторно- } \\
\text { жильного льда } \\
\text { Young ice wedge }\end{array}$ & - & 94 & 19,9 \\
\hline $\begin{array}{c}\text { Повторно-жильный } \\
\text { лед } \\
\text { Ice wedge }\end{array}$ & - & 54 & 17,0 \\
\hline
\end{tabular}

ложений в разрезе торфяника в районе с. Газ-Сале (табл. 2). Результаты опробования методом «headspace» содержания метана в 3-70 раз завышены, по сравнению с методом термовакуумной дегазации.

Следовательно, при использовании метода «headspace» в значительной степени будут занижены концентрации углекислого газа (примерно в 40 раз), так как его растворимость значительно больше. Другими словами, если проводить экстракцию методом «headspace» и измерять только содержание метана, то его концентрация будет завышена, по причине того, что метан будет первым экстрагироваться из воды, а углекислый газ и значительная часть кислорода будет оставаться в растворенной форме.

\section{Заключение}

Установлено, что газ, заключенный в многолетнемерзлых отложениях и подземных льдах, по содержанию азота и кислорода близок к атмосферному. Во льдах и мерзлом торфе выявлены большие вариации содержания метана от 4 до $1,7 \cdot 10^{4} \mathrm{ppmV}$ и углекислого газа от 7 до 2,7 $10^{3} \mathrm{ppmV}$, которые связаны с различными условиями для продуцирования и накопления парниковых газов в мерзлой толще.

Установлено преобладание содержаний углекислого газа над метаном в сегрегационных и повторножильных льдах. Максимальные концентрации метана (от $1,1 \cdot 10^{3}$ до $1,7 \cdot 10^{4} \mathrm{ppmV}$ ) обнаружены в сегрегационно-миграционных льдах бугра пучения и клиновидных льдах. Избыток метана в приповерхностных 
сегрегационно-миграционных льдах связан с его поступлением из оттаивавшей мерзлой толщи и промерзанием в замкнутой системе.

Установлены высокие содержания углекислого газа (до $1,1 \cdot 10^{3} \mathrm{ppmV}$ ) и метана (до $222 \mathrm{ppmV}$ ) в сегрегационном льду в торфе, источником этих газов является органическое вещество, разлагающееся в переменных аэробных и анаэробных условиях под действием бактерий, поэтому торфяники являются значительным источником поступления углекислого газа в атмосферу.

Проведена оценка воспроизводимости и сопоставимости методов термовакуумной дегазации и «headspace» при исследовании льдов и мерзлых отложений в разрезе торфяника в районе с. Газ-Сале. Установлено, что концентрации метана при опробовании методом «headspace» завышены в 3-70 раз по сравнению с величинами, определенными методом термовакуумной дегазации. Методом «headspace» получают завышенные содержания метана, это обу-

\section{СПИСОК ЛИТЕРАТУРЫ}

1. Bender M., Sowers T., Brook Ed. Gases in ice cores // Proc. of the National Academy of Sciences. - 1997. - V. 94 (16). - P. 8343-8349.

2. Climate and atmospheric history of the past 420,000 years from the Vostok Ice Core, Antarctida / J.R. Petit, J. Jouzel, D. Raynaud, N.I. Barkov, J.-M. Barnola, I. Basile, M. Bender, J. Chappellaz, M. Davisk, G. Delaygue, M. Delmotte, V.M. Kotlyakov, M. Legrand, V.Y. Lipenkov, C. Lorius, L. Pepin, C. Ritz, E. Saltzmank, M. Stievenard // Nature. - 1999. - V. 399. - P. 429-436.

3. The long-term ice core record of $\mathrm{CO} 2$ and other greenhouse gases D. Raynaud, J.Ch. Beeman, J. Chappellaz, F. Parrenin, J. Shin // Past Antarctica: Paleoclimatology and Climate Change. - 2020 URL: https://hal.archives-ouvertes.fr/hal-03082021 (дата обращения 25.02.2021).

4. Abrams M.A. Evaluation of near-surface gases in marine sediments to assess subsurface petroleum gas generation and entrapment // Geosciences. - 2017. - V. 7 (2). DOI 10.3390/geosciences7020035

5. Bernard B.B., Brooks J.M., Zumberge J. Determining the origin of gases in near-surface sediments // Proc. of the Near-Surface Hydrocarbon Migration: Mechanisms and Seepage Rates. Vancouver: AAPG Hedberg Conference, 2001. - P. 16-19.

6. Химический, изотопный и газовый состав однолетнего морского льда по данным кернов дрейфующих станций БАРНЕО за 2013-2015 гг. / А.И. Кизяков, И.Д. Стрелецкая, А.В. Савенко, И.А. Крайнюкова, И.В. Токарев // Лёд и Снег. - 2019. T. 59. - C. 363-376. - DOI: 10.15356/2076-6734-2019-3-387.

7. Whiticar M.J., Faber E., Schoell M. Biogenic methane formation in marine and freshwater environments: $\mathrm{CO} 2$ reduction vs. acetate fermentation-Isotope evidence // Geochimica et Cosmochimica Acta - 1986. - V. 50. - P. 693-709.

8. Whiticar M.J. Carbon and hydrogen isotope systematics of bacterial formation and oxidation of methane // Chemical Geology - 1999. - V. 161. - P. 291-314.

9. Paré M.C., Bedard-Haughn A. Landscape-scale $\mathrm{N}$ mineralization and greenhouse gas emissions in Canadian Cryosols // Geoderma. - 2012. - V. 189-190. - P. 469-479. DOI 10.1016/j.geoderma.2012.06.002.

10. Remote sensing northern lake methane ebullition / M. Engram, K.M. Walter, T. Sachs K. Kohnert, A. Serafimovich, G. Grosse F.J. Meyer // Nature Climate Change - 2020. - V. 10. - P. 511-517. DOI: $10.1038 / \mathrm{s} 41558-020-0762-8$.

11. Anaerobic oxidation of methane and associated microbiome in anoxic water of Northwestern Siberian lakes / L. Cabrol, F. Thalasso, L. Gandois, A. Sepulveda-Jauregui, K. Martinez-Cruz, R. Teisserenc, N. Tananaev, A. Tveit, M.M. Svenning, M. Barret // Science of The Total Environment. - 2020. - V. 736. DOI: 10.1016/j.scitotenv.2020.139588.

12. Climate change and the permafrost carbon feedback / E.A.G. Schuur, A.D. McGuire, C. Schaedel, G. Grosse, словлено его низкой растворимостью и преобладанием в форме нерастворенных пузырьков. Углекислый газ и часть кислорода остаются растворены в воде и не переходят в пробу газа; концентрации углекислого газа будут занижены примерно в 40 раз. Следовательно, данных о содержании газа, определенного методом «headspace», недостаточно для оценки объемов эмиссии парниковых газов, поскольку эти величины характеризуют качественный состав газа в пузырьках.

Оценку содержаний парниковых газов во льдах необходимо проводить только по результатам комплексного анализа газового состава - изучения содержаний атмосферных и парниковых газов. Также необходимо оценивать объемную долю газа в образце льда. Метод термовакуумной дегазации позволяет более достоверно рассчитать и оценить объемы поступления газов из оттаивающих мерзлых толщ. Наиболее информативными являются данные о составе газа в пузырьках и в растворенной форме.

J.W. Harden, D.J. Hayes, G. Hugelius, C.D. Koven, P. Kuhry, D.M. Lawrence, S.M. Natali, D. Olefeldt, V.E. Romanovsky, K. Schaefer, M.R. Turetsky, C.C. Treat, J.E. Vonk // Nature. 2015. - V. 520. - P. 171-179.

13. Метан в подземных льдах и мерзлых четвертичных отложениях Западного Ямала / А.А. Васильев, И.Д. Стрелецкая, В.П. Мельников, Г.Е. Облогов // Доклады Академии наук. 2015. - T. 465. - C. 604-607. DOI: 10.7868/S0869565215350236

14. Метан в подземных льдах и мёрзлых отложениях на побережье и шельфе Карского моря / И.Д. Стрелецкая, А.А. Васильев, Г.Е. Облогов, П.Б. Семенов, Б.Г. Ванштейн, Е.М. Ривкина // Лёд и Снег. - 2018. Т. - 58. - С. 65-77. DOI: 10.15356/20766734-2018-1-65-77.

15. Задорожная Н.А., Облогов Г.Е., Васильев А.А. Содержание метана в мерзлых и оттаивающих породах в ландшафтах западного побережья полуострова Ямал // Устойчивость природных и технических систем в криолитозоне: всероссийская конференция с международным участием. - Якутск: Институт мерзлотоведения им. П.И. Мельникова СО РАН, 2020. C. $263-267$.

16. Cryogenic displacement and accumulation of biogenic methane in frozen soils / G. Kraev, E.-D. Schulze, A. Yurova, A. Kholodov, E. Chuvilin, E. Rivkina // Atmosphere. - 2017. - V. 8. DOI: $10.3390 /$ atmos 8060105 .

17. Greenhouse gas production in degrading ice-rich permafrost deposits in northeastern Siberia / J. Walz, Ch. Knoblauch, R. Tigges, Th. Opel, L. Schirrmeister, E.-M. Pfeiffer // Biogeosciences. - 2018. - V. 15. - P. 5423-5436. DOI: 10.5194/bg-15-5423-2018

18. Arkhangelov A.A., Novgorodova E.V. Genesis of massive ice at 'Ice Mountain', Yenesei River, Western Siberia, according to results of gas analyses // Permafrost and Periglacial Processes. 1991. - V. 2. - P. 167-170.

19. Васильчук А.К., Васильчук Ю.К. Состав иммобилизационных (защемленных) газов и спорово-пыльцевые остатки в торфяниках Сеймчано-Буюндинской впадины // Арктика и Антарктика. - 2018. - № 4. - C. 1-15. DOI: 10.7256/24538922.2018.4.28527.

20. Methane and dissolved organic matter in the ground ice samples from Central Yamal: implications to biogeochemical cycling and greenhouse gas emission / P.B. Semenov, A.A. Pismeniuk, S.A. Malyshev, M.O. Leibman, I.D. Streletskaya, E.V. Shatrova, A.I. Kizyakov, B.G. Vanshtein // Geosciences. - 2020. - V. 10. DOI: 10.3390/geosciences10110450.

21. Гидрохимический состав и редкоземельные элементы в полигонально-жильных льдах ключевых районов криолитозоны Карского региона / В.И. Бутаков, Е.А. Слагода, Я.В. Тихонравова, О.Л. Опокина, И.В. Томберг, Н.А. Жученко // Известия Томского политехнического университета. Инжиниринг ге- 
оресурсов. - 2020. - T. 331. - № 2. - C. 78-91. DOI: $10.18799 / 24131830 / 2020 / 2 / 2483$.

22. Коленко Е.А. Технология лабораторного эксперимента: справочник. - СПб.: Политехника, 1994. - 629 с.

23. CRC handbook of chemistry and physics. 77th ed. / Ed. by D.R. Lide. - Boca Raton, USA: CRC Press, 1996. - 2496 p.

24. Особенности формирования ресурсов и химического состава воды озер восточного побережья Байкала / Е.Г. Перязева, А.М. Плюснин, С.3. Гармаева, Р.Ц. Будаев, Д.И. Жамбалова // География и природные ресурсы. - 2016. - № 5. - С. 49-59.

25. Некоторые итоги мониторинга парниковых газов в арктическом регионе России / К.Л. Антонов, В.А. Поддубный, Ю.И. Маркелов, А.Г. Буевич, А.Н. Медведев, И.Л. Манжуров // Арктика: экология и экономика. - 2018 - № 1. - С. 56-67. DOI 10.25283/2223-4594-2018-1-56-67.

26. Шакиров Р.Б., Сырбу Н.С., Обжиров А.И. Распределение гелия и водорода в отложениях и воде на склоне о. Сахалин // Литология и полезные ископаемые. - 2016. - № 1. - С. 68-81. DOI: $10.7868 / \mathrm{S} 0024497 X 16010067$

27. Геокриология СССР. Западная Сибирь / под ред. Э.Д. Ершова. М.: Недра, 1989. - 454 С.

28. Криолитологическое строение первой террасы острова Белый в Карском море: геокриологическая история и изменения природных условий (часть 3) / Е.А. Слагода, А.Н. Курчатова О.Л. Опокина, И.В. Томберг, Т.В. Ходжер, А.Д. Фирсова, Е.В.
Родионова, К.А. Попов, Е.Л. Никулина // Криосфера Земли. 2014. - T. XVIII. - № 3. - С. 33-45.

29. Особенности формирования гидрохимического и микроэлементного состава разных типов подземных льдов мыса Марре-Сале / В.И. Бутаков, Е.А. Слагода, О.Л. Опокина, И.В. Томберг, Н.А. Жученко // Криосфера Земли. - 2020. T. XXIV. - № 5. - С. 29-44.

30. Бутаков В.И., Слагода Е.А. Связь химического состава с условиями формирования линзовидного пластового льда в аллювиальных отложениях на севере п-ва Гыдан // Строение литосферы и геодинамика: XXIX Всероссийская молодежная конференция. - Иркутск: ИЗК СО РАН, 2021. - С. 55-57.

31. Гетерогенное строение полигонально-жильных льдов в торфяниках Пур-Тазовского междуречья / Я.В. Тихонравова, Е.А. Слагода, В.В. Рогов, В.И. Бутаков, А.В. Лупачёв, А.О. Кузнецова, Г.В. Симонова // Лёд и Снег. - 2020. - Т. 60. № 2. - C. 225-238. DOI: 10.31857/S2076673420020036.

32. Organic matter chemistry controls greenhouse gas emissions from permafrost peatlands / S. Sjögersten, S. Caul, T.J. Daniell, A.P.S. Jurd, O.S. O'Sullivan, C.S. Stapleton, J.J. Titman // Soil Biology and Biochemistry. - 2016. - V. 98. - P. 42-53. DOI: 10.1016/j.soilbio.2016.03.016.

33. Крицук Л.Н. Подземные льды Западной Сибири. - М.: Научный мир, 2010. - 352 с.

Поступила 22.09.2021 г.

\section{Информация об авторах}

Бутаков В.И., ведущий инженер Аналитической лаборатории физики, химии и механики мерзлых грунтов НИПИ «Нефтегазпроект», Тюменский индустриальный университет.

Cлагода $\boldsymbol{E}$.A., доктор геолого-минералогических наук, главный научный сотрудник лаборатории Комплексных методов изучения криогенных геосистем Института криосферы Земли ТюмНЦ СО РАН; ведущий научный сотрудник, Тюменский индустриальный университет.

Tихонравова Я.B., кандидат геолого-минералогических наук, научный сотрудник лаборатории Общей геокриологии Института мерзлотоведения им. П.И. Мельникова СО РАН. 
UDC 551.34:550.46

\title{
CONTENT AND COMPOSITION OF ATMOSPHERIC AND GREENHOUSE GASES IN UNDERGROUND ICE OF DIFFERENT GENESIS
}

\author{
Vladislav I. Butakov', \\ vladbutakov@yahoo.com \\ Elena A. Slagoda2,1, \\ eslagoda@ikz.ru \\ Yana V. Tikhonravova ${ }^{3}$, \\ tikh-jana@yandex.ru \\ 1 Tyumen Industrial University, \\ 38, Volodarsky street, Tyumen, 625000, Russia. \\ 2 Earth Cryosphere Institute, Tyumen scientific centre SB RAS, \\ 86, Malygin street, Tyumen, 625000, Russia. \\ ${ }^{3}$ Melnikov Permafrost Institute SB RAS, \\ 36, Merzlotnaya street, Yakutsk, 677010, Russia.
}

The relevance. The greenhouse effect is often associated with methane and carbon dioxide emission from the thawing gas-saturated icy deposits. The relationship between the increase in concentrations of greenhouse gases in the atmosphere and their content in underground ice and frozen deposits has not been sufficiently studied. Different and incomparable methods of gas sampling from frozen deposits and ice are used to assess the content of gases in sediments and ice, the volume of gases entering the atmosphere. When generalizing the data on carbon emissions in the Arctic zone, it is necessary to take into account both the methods of determining the content and composition of gases and the different chemical composition, the presence of organic and mineral inclusions in genetic types of underground ice.

The aim of the research is to determine the results of different methods of gas sampling from ice and to establish the relationship between the content and composition of gases in common genetic types of ground ice.

Objects: genesis types of ice (segregated, closed-cavity, and ice wedge), icy frozen deposits of the north of Western Siberia: on the Bely island, on Western Yamal, on the north of Gydan and the Pur-Taz interfluve, collected in expeditions of the Earth Cryosphere Institute, Tyumen scientific center SB RAS in 2014-2019.

Research methods and interpretation of chemical composition. The thermal vacuum degassing method and the "headspace» method were used for gas extraction from frozen monoliths and ice. The thermal vacuum degassing method in laboratory conditions with the determination of the gas volume in the ice sample was used as a reference. The method of gas chromatography was applied to determine the composition of atmospheric and greenhouse gases. Gas content in ice and gas content in frozen peat that contains gas in the atmosphere, and the values of the gas solubility in water were compared. The correlation analysis of the gas content in common types of underground ice, as well as frozen peat, was carried out.

Results. It was established that gas entrapped in ground ice and frozen peat was similar to atmospheric gas in terms of the relative content of nitrogen and oxygen. It was found out the large variations in methane content from 4 to $1,7 \cdot 10^{4} \mathrm{ppmV}$ and carbon dioxide from 7 to 2,7.103 ppmV in samples are associated with different conditions for production and accumulation of greenhouse gases in the permafrost. The prevalence of carbon dioxide content over methane in segregated ice and ice wedge was established, and maximum methane concentrations (from $1,1 \cdot 10^{3}$ to $1,7 \cdot 10^{4} \mathrm{ppmV}$ ) in segregated-migration ice of heaving mound and wedge-shaped ice. An excess of methane in the near-surface segregated-migration ice is associated with its accumulation in thawed talik deposits and subsequent ice formation during freezing in a closed system. High concentrations of carbon dioxide (up to 1,1 103 ppmV) and methane (up to $222 \mathrm{ppmV}$ ) in segregated ice in peat were found; their source is organic matter degradation under variable aerobic and anaerobic conditions under the action of bacteria. As a result, the peatlands are a significant source of carbon dioxide emissions into the atmosphere. Assessing reproducibility and comparability of the methods of thermal vacuum degassing and "headspace» was carried out in the study of ice and frozen sediments in the cross section of peat bog in the area of the village Gaz-Sale. It was found that methane concentrations during testing by the «headspace» method are overestimated by 3-70 times in comparison with the values determined by the method of thermal vacuum degassing. This is due to the low solubility of methane and its predominance in bubbles, while carbon dioxide and some oxygen remain dissolved in water and do not pass into the gas sample. Consequently, the data on the gas content determined by the "headspace» method is insufficient to estimate the volumes of greenhouse gas emissions, since these values characterize the qualitative composition of the gas in the bubbles. Thermal vacuum degassing method allows calculating and estimating the volumes of gas receipts from thawing permafrost.

Key words:

Greenhouse gases, ground ice, biogenic methane, gas-saturated deposits, thermal vacuum degassing method, «headspace» method.

\section{REFERENCES}

1. Bender M., Sowers T., Brook Ed. Gases in ice cores. Proceedings of the National Academy of Sciences, 1997, vol. 94, pp. 8343-8349.

2. Petit J.R., Jouzel J., Raynaud D., Barkov N.I., Barnola J.-M., Basile I., Bender M., Chappellaz J., Davisk M., Delaygue G.,
Delmotte M., Kotlyakov V.M., Legrand M., Lipenkov V.Y., Lorius C., Pepin L., Ritz C., Saltzmank E., Stievenard M. Climate and atmospheric history of the past 420,000 years from the Vostok Ice Core, Antarctida. Nature, 1999, vol. 399, pp. 429-436.

3. Raynaud D., Beeman J.Ch., Chappellaz J., Parrenin F., Shin J. The long-term ice core record of $\mathrm{CO}_{2}$ and other greenhouse gases. Past 
Antarctica: Paleoclimatology and Climate Change, 2020. Available at: https://hal.archives-ouvertes.fr/hal-03082021 (accessed 25 February 2021).

4. Abrams M.A. Evaluation of near-surface gases in marine sediments to assess subsurface petroleum gas generation and entrapment. Geosciences, 2017, vol. 7. DOI: 10.3390/geosciences 7020035 .

5. Bernard B.B., Brooks J.M., Zumberge J. Determining the origin of gases in near-surface sediments. Proceedings of the near-surface hydrocarbon migration: mechanisms and seepage rates. Vancouver, AAPG Hedberg Conference, 2001. pp. 16-19.

6. Kizyakov A.I., Streletskaya I.D., Savenko A.V., Kraynyukova I.A., Tokarev I.V. Chemical, isotopic and gas composition of the firstyear sea ice in 2013-2015 from the data of cores taken at the BARNEO drifting stations. Ice and Snow, 2019, vol. 59, no. 3, pp. 363-376. In Rus. DOI: 10.15356/2076-6734-2019-3-387.

7. Whiticar M.J., Faber E., Schoell M. Biogenic methane formation in marine and freshwater environments: $\mathrm{CO}_{2}$ reduction vs. acetate fermentation-Isotope evidence. Geochimica et Cosmochimica Acta, 1986, vol. 50, pp. 693-709.

8. Whiticar M.J. Carbon and hydrogen isotope systematics of bacterial formation and oxidation of methane. Chemical Geology, 1999, vol. 161, pp. 291-314.

9. Paré M.C., Bedard-Haughn A. Landscape-scale N mineralization and greenhouse gas emissions in Canadian Cryosols. Geoderma, 2012, vol. 189-190, pp. 469-479. DOI: 10.1016/j.geoderma. 2012.06.002.

10. Engram M., Walter K.M., Sachs T., Kohnert K., Serafimovich A., Grosse G., Meyer F.J. Remote sensing northern lake methane ebullition. Nature Climate Change, 2020, vol. 10, pp. 511-517. DOI: $10.1038 / \mathrm{s} 41558-020-0762-8$.

11. Cabrol L., Thalasso F., Gandois L., Sepulveda-Jauregui A., Martinez-Cruz K., Teisserenc R., Tananaev N., Tveit A., Svenning M.M., Barret M. Anaerobic oxidation of methane and associated microbiome in anoxic water of Northwestern Siberian lakes. Science of The Total Environment, 2020, vol. 736. DOI: 10.1016/j.scitotenv.2020.139588

12. Schuur E.A.G., McGuire A.D., Schaedel C., Grosse G., Harden J.W. Hayes D.J., Hugelius G., Koven C.D., Kuhry P., Lawrence D.M., Natali S.M., Olefeldt D., Romanovsky V.E., Schaefer K., Turetsky M.R., Treat C.C., Vonk J.E. Climate change and the permafrost carbon feedback. Nature, 2015, vol. 520, pp. 171-179.

13. Vasiliev A.A., Streletskaya I.D., Melnikov V.P., Oblogov G.E. Methane in ground ice and frozen Quaternary deposits of Western Yamal. Doklady Earth Sciences, 2015, vol. 465, pp. 1289-1292. DOI: $10.1134 / \mathrm{S} 1028334 \mathrm{X} 15120168$.

14. Streletskaya I.D., Vasiliev A.A., Oblogov G.E., Semenov P.B., Vanshtein B.G., Rivkina E.M. Methane in ground ice and frozen sediments in the coastal zone and on the shelf of Kara sea. Ice and Snow, 2018, vol. 58, pp. 65-77. In Rus.

15. Zadorozhnaya N.A., Oblogov G.E., Vasiliev A.A. Soderzhanie metana v merzlykh i ottaivayushchikh porodakh v landshaftakh zapadnogo poberezhya poluostrova Jamal [Methane content in the frozen and thawing ground and methane fluxes of Marre-Sale station landscapes (Yamal peninsula)]. Ustoychivost prirodnykh $i$ tekhnicheskikh sistem $v$ kriolitozone. Vserossiyskaya konferentsiya $s$ mezhdunarodnym uchastiem [Environmental and infrastructure integrity in permafrost regions. Proceedings of the All-Russian Conference with International Participation]. Yakutsk, Permafrost Institute SB RAS Press, 2020. pp. 263-266.

16. Kraev G., Schulze E.-D., Yurova A., Kholodov A., Chuvilin E., Rivkina E. Cryogenic displacement and accumulation of biogenic methane in frozen soils. Atmosphere, 2017, vol. 8. Available at: https://doi.org/10.3390/atmos8060105 (accessed 25 February 2021).

17. Walz J., Knoblauch Ch., Tigges R., Opel Th., Schirrmeister L., Pfeiffer E.-M. Greenhouse gas production in degrading ice-rich permafrost deposits in northeastern Siberia. Biogeosciences, 2018, vol. 15, pp. 5423-5436. DOI: 10.5194/bg-15-5423-2018

18. Arkhangelov A.A., Novgorodova E.V. Genesis of massive ice at 'Ice Mountain', Yenesei river, Western Siberia, according to results of gas analyses. Permafrost and Periglacial Processes, 1991, vol. 2, pp. 167-170.

19. Vasilchuk A.C., Vasilchuk Y.K. The composition of trapped gases and pollen in the polygonal peat Seymchan-Buyunda depression. Arctic and Antarctica, 2018, no. 4, pp. 1-15. In Rus. DOI: 10.7256/2453-8922.2018.4.28527.

20. Semenov P.B., Pismeniuk A.A., Malyshev S.A., Leibman M.O., Streletskaya I.D., Shatrova E.V., Kizyakov A.I., Vanshtein B.G. Methane and dissolved organic matter in the ground ice samples from Central Yamal: implications to biogeochemical cycling and greenhouse gas emission. Geosciences, 2020, vol. 10, no. 11. DOI: 10.3390/geosciences 10110450

21. Butakov V.I., Slagoda E.A., Tikhonravova Y.V., Opokina O.L., Tomberg I.V., Zhuchenko N.A. Hydrochemical composition and rare-earth elements in polygonal wedge ice of the Kara region cryolitozone key area. Bulletin of the Tomsk Polytechnic University. Geo Assets Engineering, 2020, vol. 331, no. 2, pp. 78 91. In Rus. DOI: 10.18799/24131830/2020/2/2483. In Rus.

22. Kolenko E.A. Tekhnologiya laboratornogo eksperimenta: spravochnik [Laboratory experiment technology: handbook]. St. Petersburg, Politekhnika Publ., 1994. 629 p.

23. Lide D.R. CRC handbook of chemistry and physics. $77^{\text {th }}$ ed. Boca Raton, CRC Press, 1996. $2496 \mathrm{p}$

24. Peryazeva E.G., Plyusnin A.M., Garmaeva S. Z., Budaev R. Ts., Zhambalova D. I. Features of the formation of chemical composition of lake waters along the eastern shores of Baikal. Geography and Natural Resources, 2016, no. 5, pp. 49-59. In Rus.

25. Antonov K.L., Markelov Y.I., Markelov Y.I., Buevich A.G., Medvedev A.N., Manzhurov I.L. Some results of greenhouse gases monitoring in the Arctic region of Russia. Arctic: Ecology and Economy, 2018, vol. 29, no. 1, pp. 56-67. In Rus. DOI: 10.25283/2223-4594-2018-1-56-67.

26. Shakirov R.B., Syrbu N.S., Obzhirov A.I. Distribution of helium and hydrogen in sediments and water on the Sakhalin slope. Lithology and Mineral Resources, 2016, vol. 51, pp. 61-73.

27. Geokriologiya SSSR. Zapadnaya Sibir [Geocryology of the USSR. Western Siberia]. Ed. by E.D. Ershov. Moscow, Nedra Publ., 1989. $454 \mathrm{p}$.

28. Slagoda E.A., Kurchatova A.N., Opokina O.L., Tomberg I.V., Khodzher T.V., Firsova A.D., Rodionova E.V., Popov K.A., Nikulina E.L. Cryostratigraphy of the first terrace in Bely Island, Kara Sea: Permafrost and climate history (Part 3). Earth's Cryosphere, 2014, vol. XVIII, no. 3, pp. 32-43.

29. Butakov V.I., Slagoda E.A., Opokina O.L., Tomberg I.V., Zhuchenko N.A. The formation features of the hydrochemical and trace element composition of various types of ground ice at MarreSale Cape. Earth`s Cryosphere, 2020, vol. XXIV, no. 5, pp. 29-44. In Rus.

30. Butakov V.I., Slagoda E.A. Svyaz khimicheskogo sostava s usloviyami formirovaniya linzovidnogo plastovogo lda $\mathrm{v}$ allyuvialnykh otlozheniyakh na severe p-va Gydan [Relationship between the chemical composition and the conditions for the formation of ice lens in alluvial sediments on the north of the Gydan Peninsula]. Stroenie litosfery $i$ geodinamika. XXIX Vserossiyskaya molodezhnaya konferentsiya [XXIX All-Russian Youth Conference. Structure of the Lithosphere and Geodynamics]. Irkutsk, Institute of the Earth's crust, Siberian Branch, Russian Academy of Sciences, 2021. pp. 55-57.

31. Tikhonravova Y.V., Slagoda E.A., Rogov V.V., Butakov V.I., Lupachev A.V., Kuznetsova A.O., Simonova G.V. Heterogeneous ices in ice wedges structure on the Pur-Taz interfluve peatlands of the north of West Siberia. Ice and Snow, 2020, vol. 60, no. 2, pp. 225-238. In Rus. DOI: 10.31857/S2076673420020036.

32. Sjögersten S., Caul S., Daniell T.J., Jurd A.P.S., O'Sullivan O.S., Stapleton C.S., Titman J.J. Organic matter chemistry controls greenhouse gas emissions from permafrost peatlands. Soil Biology and Biochemistry, 2016, vol. 98. pp. 42-53. DOI: 10.1016/j.soilbio.2016.03.016.

33. Kritsuk L.N. Podzemnye ldy Zapadnoy Sibiry [Ground ice of West Siberia]. Moscow, Nauchny Mir Publ., 2010. 352 p. 


\section{Information about the authors}

Vladislav I. Butakov, lead engineer, Analytical laboratory of physics, chemistry and mechanics of frozen soils, scientific research and design institute «Neftegazproekt», Tyumen Industrial University.

Elena A. Slagoda, Dr. Sc., principal researcher, Earth Cryosphere Institute, Tyumen scientific centre SB RAS; leading researcher, Tyumen Industrial University.

Yana V. Tikhonravova, Cand. Sc., researcher, Melnikov Permafrost Institute SB RAS. 